Southern Illinois University Carbondale

OpenSIUC

Articles

Department of Criminology and Criminal Justice

2009

\title{
Toward a Criminology of International Criminal Law: An Integrated Theory of International Criminal Violations
}

Dawn L. Rothe

Old Dominion University

Christopher W. Mullins

Southern Illinois University Carbondale, mullinsc@siu.edu

Follow this and additional works at: http://opensiuc.lib.siu.edu/ccj_articles This is an Author's Accepted Manuscript of an article published in International Journal of Comparative and Applied Criminal Justice, Vol. 33, No. 1 (2009) (copyright Taylor \& Francis), available online at: http://www.tandfonline.com/10.1080/01924036.2009.9678798.

This Article is brought to you for free and open access by the Department of Criminology and Criminal Justice at OpenSIUC. It has been accepted for inclusion in Articles by an authorized administrator of OpenSIUC. For more information, please contact opensiuc@lib.siu.edu. 
Toward a Criminology of International Criminal Law: An Integrated Theory of International Criminal Violations

\author{
Dawn L Rothe
}

Christopher W Mullins 


\begin{abstract}
Violations of international criminal law are a common occurrence around the globe. One need only to read international news or visit intra-governmental (e.g., United Nations or the International Committee Red Cross) or non-governmental organizations (e.g., Human Rights Watch or Amnesty International) to be exposed to the vast numbers of crimes of states, paramilitaries, and/or militias (e.g. the genocide in Sudan, the continued chaos, civil strife and abuse of civilians in the Democratic Republic of Congo, the protracted war between the Lord's Resistance Army (LRA) and the government of Uganda, etc). Nonetheless, there has been relatively little attention paid to these types of offenses by criminologists. Moreover, due to the complexities of these types of atrocities there has been little to no development of a theoretical model that can aid in the analysis of such crimes. As such, our goal with this article is to firmly place international crimes on the criminological agenda by creating additional awareness of and interest in the most massive, systematic, and gruesome types of crime; genocide, crimes against humanity, war crimes, crimes of aggression and other gross human rights violations, and to introduce an integrated theory that can provide a frame for systematic analysis of and an understanding of the etiological factors at play.
\end{abstract}

Key Words:

Integrated Theory, Atrocity, International Criminal Law Violations, State Crime 
Biographical Information:

Dawn L. Rothe obtained her PhD from Western Michigan University. Currently she is an Assistant Professor at the University of Northern Iowa. Rothe serves as Chair of the Midwest Sociological Society Social Action Committee, editor of the American Society of Criminology Division of International Criminology Newsletter and, co-editor for the American Society of Criminology Division of Critical Criminology Newsletter. She is the author of over thirty articles appearing in Social Justice, Humanity and Society, Crime, Law, and Social Change, and Journal of Critical Criminology and book chapters as well as author of Symbolic Gestures and the Generation of Global Social Control (2006) published by Lexington (co-authored with Christopher W. Mullins) and co-author of Power, Bedlam, and Bloodshed: State Crimes in Post-Colonial Africa (2008) published by Peter Lang.

Christopher W. Mullins is an Assistant Professor of Criminology at the University of Northern Iowa. He is the co-author, with Dawn Rothe, of Symbolic Gestures and the Generation of Global Social Control (2006) published by Lexington and the author of Holding Your Square: Masculinities, Streetlife and Violence (2006) published by Willan and Blood, Power and Bedlam: State Crimes in Post-Colonial Africa (2008) published by Peter Lang.(co-authored with Dawn L Rothe). His work has appeared in Criminology, The British Journal of Criminology, Critical Criminology, Contemporary Justice Review, and Humanity and Society, among other places. 


\section{Toward Criminology of International Criminal Law: An Integrated Theory of International Criminal Violations Introduction}

Violations of international criminal law are a common occurrence around the globe. One need only to read international news or visit intra-governmental (e.g., United Nations or the International Committee Red Cross) or non-governmental organizations (e.g., Human Rights Watch or Amnesty International) to be exposed to the vast numbers of crimes of states, paramilitaries, and/or militias (e.g. the genocide in Sudan, the continued chaos, civil strife and abuse of civilians in the Democratic Republic of Congo, the protracted war between the Lord's Resistance Army (LRA) and the government of Uganda, etc). Nonetheless, there has been relatively little attention paid to these types of offenses by criminologists. Moreover, due to the complexities of these types of atrocities there has been little to no development of a theoretical model that can aid in the analysis of such crimes. The extant criminological research on atrocities such as genocide, crimes against humanity, war crimes, and/or crimes of aggression have either focused on the methodologies for verifying numbers of victims (see Hagan 2006), post-trauma responses and controls (see here), crimes of globalization (see Rothe, Mullins, and Sandstrom 2008) or have been placed under the category of state crime (Friedrichs YR; Kauzlarich and Kramer 1998; Kramer and Michalowski 2005; Mullins and Rothe 2007; and Rothe and Mullins 2006).

The categorization of these types of atrocities as state crime or as a form of crimes of globalization has indeed led to the development of several case studies and generated additional attention to criminology's role in understanding the worst of international crimes yet, we believe that such atrocities do not always fit neatly into the category of 
crimes of the state. For example, Kramer and Michalowski (2005) defined state crime as any action violating public international law, international criminal law, when these actions are committed by individuals acting in official or covert capacity as agents of the state pursuant to expressed or implied orders of the state. Indeed, in some cases regimes are directly or indirectly involved in such atrocities. However, in many of these atrocities paramilitaries and or militias play a central role. They are not agents of the state. While there are cases of militias working for or with governmental support (e.g., the Janjaweed and the Sudanese government), we cannot ignore those that do not (e.g., Lord's Resistance Army in Uganda) nor should we misclassify them as state crimes. In some cases, such as the Democratic Republic of the Congo, the government and its role in the atrocities occurring there is too weak or nonexistent to be classified as state crime. In others, the main actors are transnational organizations, with little state involvement. On the other hand, the International Monetary Fund or the World Bank group may be indirectly involved in the atrocities, fitting into a category of crimes of globalization. As such, attempting to fit violations of international criminal law into one general typology can be problematic. This is yet another reason why any theoretical development must be complex and general enough to address the multiple forms and means of these atrocities.

Consequentially, our goal with this article is to not only place international crimes on the criminological agenda by creating additional awareness of and interest in the most massive, systematic, and gruesome types of crime; genocide ${ }^{\mathrm{i}}$, crimes against humanity ${ }^{\mathrm{ii}}$, war crimes ${ }^{\mathrm{iii}}$, crimes of aggression and other gross human rights violations, but to introduce an integrated theory that can provide a frame for systematic analysis and understanding of the etiological factors at play. After all, many mainstream and critically- 
orientated theories of crime and criminality have relevance to the explanation of violations of international criminal law, yet, standing alone each contains serious shortcomings.

We begin with a brief overview of criminological theoretical research used to analyze crimes of the state and other relevant theories. From there we present our integrated theory of 'supranational' crimes. Simply, our aim is to introduce readers to the idea of a criminology of international criminal law and to provide a general overview of how an integrated criminological theory can provide a richer understanding of these crimes.

\section{Theory Building:}

\section{Towards International Violations of International Law}

Traditional criminological inquiry has, for the most part, produced theories addressing one specific level of analysis. While some scholars have ventured into integrating traditional theories, they have done so by integrating theories addressing the same level of analysis. Further, due to the complexities of these atrocities, utilizing theories that explain only the individual level processes, that of organizations, controls, or external precipitating conditions is bound to overlook the complexities of such cases and provide no additional guidance for future understandings of atrocities or ability to foresee potential situations prior to becoming full-blown violations of international criminal law. While this may be an acceptable form of integration for some, we believe that an analysis of phenomena that has such complexities as time-space, history, culture, politics, ideology, and economics must include an integrated model that addresses all levels of analysis: the structural to the individual(s) involved in the crimes. 
Despite Gottfried son and Hirschi's (1992) insistence against theoretical integration, especially when theories have potentially contradictory base-assumptions, we feel that integration is the most viable path forward for theorizing the types of crimes we seek to here. First, to ignore extant theory is to be forced to remake the wheel. Such a posture is not only myopic in that it ignores decades of establish theorizing and theory testing, it is arrogant in its rejection of what has come before. Further, we feel that the debate which Gottfriedson and Hirschi (1992) have stimulated is misplaced and misconceptualized. The core question, for example, is not whether social bonding theory's assumptions about inherent motivation are contradicted by learning theory's assumptions of motivation as learned. The question should be whether or not a reasonable empirical linkage exists between a given model's core indicators. "Human nature" as such is a black box concept which cannot be observed or even inferred with any degree of accuracy. However, decades of research have established that certain phenomena are related to crime commission. The job then of an integrationist is to provide an underlying framework (and set of assumptions) that make sense of empirical reality.

We are not the first scholars to present an integrated theoretical model of corporate or governmental offending. This paper builds explicitly off of the theoretical frame by Kauzlarich and Kramer (1998), which itself built of earlier work by Kramer and Michalowski (1990), presented an integrated model of state offending that explored motivation, opportunities, and controls at three levels of analysis: the interactional, organizational, and the cultural-structural level. Moreover, their model integrates components of several criminological theories that fall short by themselves in addressing state crime. For example, Kauzlarich and Kramer utilize anomie and strain, rational 
choice, differential association, routine activities, political economy, and organizational models. Kauzlarich and Kramer discuss how motivation is affected by one's socialization within that environment, the social meaning given to their behavior, an individual's goals, and issues of personality such as personal morality and obedience to authority. Borrowing from Sykes and Matza, they include techniques of neutralization as a variable of control. At the organizational level, Kauzlarich and Kramer draw heavily from organizational theorists who argue that "there is built into the very structure of organizations an inherent inducement for the organization itself to engage in crime" (Gross quoted in Kauzlarich and Kramer 1998: 145). They, along with organizational theorists, argue that organizations are strongly goal-oriented ${ }^{\mathrm{iv}}$ and concerned with performance while governing norms may be weak or absent (anomie). Moreover, these goals may be blocked internally or externally causing strain (e.g., standard operating procedures or codes of conduct). As Kauzlarich and Kramer argue, organizational crime depends on two other factors-availability of illegal means and the social control environment that fosters organizational crime (146). Organizational opportunities are said to include instrumental rationality, role specialization, and task segregation while controls include a culture of compliance, reward structure, safety and quality control procedures, and effective communication processes.

At the structural or institutional level of analysis, the major social institutions and social structure are included; particularly the political and economic institutions and their interrelationship merit special attention in explaining organizational crime. They suggest the primary assumption of that perspective is that the very structure of corporate capitalism provides the impetus toward organizational crime (146), thus becoming crimes 
of capital (Michalowski 1985). They further propose that the political economy perspective stresses the shaping and/or constraining influences of the broader historical structure of a society as a factor on organizational behavior. This includes factors such as the culture of competition, economic pressure, and performance emphasis under the catalyst of motivation. Also needed is the availability of legal and illegal means, blocked goals, and access to resources that are included under opportunities. Controls at the structural level are said to include international reactions, political pressure, legal sanctions, media scrutiny, and public opinion.

While we find this to be one of the most useful models in existence due to its integrated and multi-level nature, we believe it fails to adequately incorporate the increasingly international nature of criminality, especially cases that do not involve typical western capitalistic based forms of state crime. Further, as it stands in the works cited above, it is more or a theory that allows illumination of cases, instead of empirical prediction and testing.

Save for recent work on crimes of globalization (see Friedrichs and Friedrichs 2002; Rothe, Muzzatti and Mullins 2006; Rothe, Mullins and Sandstrom 2008) most organizational criminology, including state crime, has ignored the social forces and incipient social structures occurring within the international realm in favor of focusing on a state itself. Further, when the international arena is taken into account it is done so in a rather simplistic manner resting upon a highly idealized and reified account of globalization (Whyte 2003). While an international context may be assumed, it is not fully specified or conceptualized in how it influences decision making at the state level. What ever occurs at the supra-national level is perceived as a state-level influence. State 
policies are viewed as inevitably market driven as such, the focused is limited to the dynamics of a global and capitalistic economy, most notably, U.S. centered. However, the institutional elements and context of a state, it's economic, political, cultural, and historical environment, is distinct from and often exhibiting forces in contradiction with those elements at the international level. These forces may influence the nature of social forces within a state's macro-level structure, but can also exert their own unique influences. Any given state, and the social structure it represents, will be the product of long-term historical contingencies and forces that necessitate an examination of factors more traditionally referred to as macro-level forces. Broader cultural, political and economic factors in play at a given time and space can to a greater or lesser extent produce a given crime.

For example, the cases currently under investigation at the ICC share a similar history of colonial rule (e.g., Uganda, the Democratic Republic of Congo (DRC), Chad and The Sudan). However, such historical conditions did not result in consistent postindependence outcomes. Uganda's transition to independence was relatively peaceful, with internecine conflict erupting well into the post-indepence phase of its history. Uganda inherited a stable economic and political structure. Contrarily, the DRC tore itself apart in regional revolution within days of Belgium granting the Congo her indepence. Issues of states' specific religions, resources, and geographic and/or ethnic divisions were also factors leading up the events under investigation at the court. Uganda's problems have largely been the result of two varying power bases competing for control over the nation and her resources; the DRC has shown scores of groups with shifting alliances and affiliations fighting betwixt and between themselves and each for control of regional 
resource bases. Thus, ignoring these state-level differences fails to holistically address the etiological and structural factors of the given crimes.

Since many of these crimes are committed within an organizational structure (states, paramilitaries, militaries, etc) one must explore factors at play within the organization itself. While the Kauzlarich and Kramer model (1998) incorporates elements of organizational theory, it is limited to highly bureaucratic institutions or those based on capitalistic profit generating tendencies. Broader theories of organizational behavior and corporate offending highlight certain organizational structures may develop bureaucratic environments where goal attainment is pushed to an "any means necessary" degree. Certain organizations further reinforce instrumental rationality within decision making processes (see Perrow 1986; Weber 1946) that can enhance the perceived value of criminal behaviors and reduce the perceived harm of the same act. Cultures can develop within organizations or subunits that can motivate criminal endeavors (see Sutherland 1949). The very nature of complex organizations provides a host of opportunity producing elements. Bureaucracies can maintain levels of secrecy on how their resources are utilized; external actors need not know what was done within the organization or by whom. Information may also be hidden from other organizational actors, including those who are actually carrying out elements of the criminal activity. Due to internal organizational structures of information control, the ability of external agencies to obtain information on the nature and dynamics of these decision-making events heighten criminal tendencies (Rothe and Mullins 2006c).

As corporate crime researchers have shown, some organizations are much more criminogenic than others. As we present in our model and have suggested elsewhere, 
many of these types of crimes are committed by militias and paramilitaries that do not fit into the organizational model conceived by many organizational theorists. As such, the social processes and a broader conception of organizational cultures is essential in understanding these crimes. For example, The Lord's Resistance Army's long-standing opposition to the Ugandan government is the product of post-colonial political forces and the end result of series of coups and counter-coups. The operative ideology of the LRA is religious in nature, replicating the discourse of Alice/Laweka of the Holy Spirit Movement Army. Further, there is an ethic basis to the LRA, as it is mostly composed of Acholi from the Ankula region. Within the same conflicts, the Ugandan armed forces the Ugandan People's Defense Forces (UPDF) have also committed vast atrocities on citizens in refugee camps. For example, state troops stationed as guard for displaced persons camps frequently intimidate, rob and rape women as they leave to collect firewood and other essentials. Men who leave are often beaten or murdered. These men are not acting on orders but simply abusing the position of power they inhabit. In contrast, the Sudanese regime has actively supported the Janjaweed militia in carrying out massive crimes against humanity not for profit or due to its bureaucratic structure, but instead through motivations based on alliances for political reasons that aid their agenda. Governmental forces aid in the militias atrocities as well as abide by a systematic state policy focusing on continuing the violence and crimes at hand. The government provides payment, arms and other equipment for the Janjaweed, as well as its marching orders. Thus, while superficially similar, each of these cases exhibits a complexity of organizational forces. Further, looking beyond the capitalistic notion of organizational structures as corporate entities, we find that within certain organizations the presence of a 
reward structure does not ensure compliance, instead it creates the very crimogenic tendencies that scholars have believed reduce or control criminality.

There is also a need to include aspects of associational and social learning theories (e.g., Akers 1977; Sutherland 1939) and core elements of symbolic interactionism (e.g., perceptual aspects and definition of the situation) to understand these phenomena. As noted by Sutherland (1949:300), “Any person can be trained to adopt and follow a pattern of criminal behavior". The idea of learning criminal behaviors through socialization is not only relevant in organizational settings but also in a larger cultural setting. Again, cultural elements discussed above come to bear-both in the broader socio-cultural sense and organizational cultures which the individual has been socialized into. Certain organizations may inculcate actors into broader ideological beliefs that facilitate violating laws; day-to-day interactions provide ample opportunity for the transmission not only of criminogenic value systems but also of neutralizations to excuse such behaviors. Akers (1973, 1977, 1996, 1998) social learning theory wherein: 1) deviant behavior is learned through operant conditioning; 2) the behavior is learned nonsocially and through social interaction vis a vis reinforcements; 3 ) the major part of deviant behavior is learned in groups that control the major source of reinforcements; and 4) the learning of techniques, attitudes, avoidance is a function of re-enforcers.

This model is useful combined with Sutherland's Differential Association for providing an understanding in some cases. For example, as seen with child-soldiers who are forced to commit atrocities, the process of stimuli presentation-negative and positiveis routinely used to ensure obedience. Child soldiers are motivated/rewarded with personal praise, social inclusion, drugs and valuable items. They are also brutally 
disciplined, or forced to carry out beatings on their peers as both punishment and conditioning. Further, new child recruits are trained and socialized into the militia by their peers.

A separate body of criminological theory emphasizes the influence of social disorder within immediate residential environments as having powerful criminogenic effects. Typically referred to as social disorganization theory (see Shaw and McKay 1942; Bursik and Grasmick 1993), this line of theorizing suggests that when communities posses a diminished capacity to create and enact informal mechanisms of social control, or exhibit levels of collective efficacy, crime rates increase due to the lack of community self-organization. Essential a control theory of crime, this work points out that indicators of concentrated disadvantage are largely responsible for the reduction of a community's ability to act collectively. Additionally, European and American criminologists have established that these disorganized social environments also have a pronounced tendency to produce criminal enterprises of varying levels of organizations—be they street gangs, mafia groups, crime syndicates, or drug cartels. In the absence of legitimate forms of social organization, illegal organizations—or at least groups who engage in persistent criminal behavior-proliferate to provide social structures and opportunities absent due to broader conditions of institutional failures. Here, wide-spread social disorganization is most readily apparent in producing militias.

Widespread abject poverty, a lack of functioning infrastructure and social institutions severely undercut by de-colonization creates a profound vacuum of social order. These illicit organizations arise in such contexts to structure life and provide opportunities for community members to realize meaningful social identities. Militias 
specifically operate in this fashion. Not only do they provide much need community defense, but they also provide a normative environment to give social actors bereft to opportunity a real social location. Further, they are often the only meaningful opportunity for income and self empowerment.

A related, yet separate, concept to social disorganization is anomie. Unlike Kauzlarich and Kramer (1998), we use anomie in the Durkheimien sense wherein anomie assumes that rapid social change has had mass societal affects that led to normlessness in a structure that has lack of social constraints or regulation. While no longer applicable to conditions of rapid social change envisioned by Durkheim, the transition from mechanical to organic society, the relevance of anomie understood in these terms can be seen with conditions left by abrupt colonial departures or coups, often dismantling entire sets of socio-political structures. Not only do such events rearrange governmental structures, the organization of economic ownership and production are reconfigured as well.

Weak institutions produce a vacuum of formal and informal social control. A country unable to adequately police or subdue a paramilitary force in its hinterlands creates a gap of institutional control that simultaneously provides motivation and opportunity for the arisal of organized criminal activity. Informal controls, such as modalities of socialization, behavioral controls operating within other institutions such as the family, education, or religion, are distinctly weakened in these environments. This allows for more easeful transmission of subcultural values allowing and encouraging criminality, as well as other beliefs which can feed into criminogenic forces (e.g., racism aiding genocidal events). On the other hand, Durkheim and others such as Colvin and 
Cullin (2004) have recognized that overregulation can also create crimogenic

environments at the state level. For example, history has shown that overregulated nationstates have resulted in terrible atrocities such as the Soviet Gulag system. Further, the vast literature on the Holocaust points to the hyper-centralization of power during the Nazi regime as both motivation and facilitation of the genocide at all levels of analysis. Merton's (1938) classic structure-strain theory is also of relevance. While often presented as one theory, Merton proposed two separate theoretical concepts, anomie and strain. According to Merton, strain occurs when attaining culturally emphasized goals and expectations are unattainable, either due to blocked goals or means. As such, the intrinsic value of following norms is meaningless without the attainment of the goals. Further, to attain these by institutionalized means is not as important as the end means of having attained them. As such, criminality stems from blocked goals. We see strain operating in different forms when anomic conditions or those from highly social disorganized areas. For example, through years of political turmoil and marginalization, many militia groups enact alternative means to accomplish political capital, including coups and/or insurgencies that are directly related to the atrocities this theory aims to explain (e.g., LRA in Uganda or the Darfur insurgency that sparked the Sudanese government's harsh military response and collusion with the Janjaweed).

In line with the majority of traditional criminological theories, we do not ignore the influence of individuals and individual decision makers within these events in explaining criminality. All acts require that a singular social actor make a decision and produce an act. In any crime involving state, militia, or paramilitary actors, orders to carry out the activities must be developed, agreed upon, and enacted. Within a 
bureaucracy as complex as a polity, this involves not one, but a multitude of social actors in a number of organizational positions. Structure clearly frames action and thought, channeling human behavior toward certain outcomes and away from others; it defines possibilities and molds goal structures. Social actors respond to stimuli within their environments, yet exercise individual choice in decision-making processes based on any number of variables. While individual agency is indeed modified or even extremely constrained by the social conditions present within any complex organization, no bureaucratic actor is a mere automaton. Individuals carry with them pre-established cultural and ideological visions. Such lens influence how they evaluate information, create policy objectives and direct organization activities to the realization of those policies. More essentially, at the top levels of power, agency can often be fully revealed and active. While indeed processes like groupthink can come into play, original decisions, directives, and directions must be established through some form of agentic decision making process. While such individual predilections and predispositions are often overlooked, it must be acknowledged that the perpetrators and the decision-makers in these cases possess agency. They are not automatons blindly responding to sociopolitical forces, but rather lively social actors who often wield large amounts of social power and institutional authority that can be brought to bear in the commission of a crime.

State crime scholars have identified external and internal controls on the behavior of states (see Ross 1995, 2000). External controls have been defined as those that lie outside of the specific state apparatus and are imposed on the state itself. Internal controls are those that arise within the state and are directed against itself such as previously 
discussed domestic laws and self-regulation. These controls can be tangible (i.e., the firing of an agent) or symbolic (i.e., an official statement of denial or a promise to investigate). Internal controls are broadly conceived of as restrictions placed on state agencies by themselves or other state agencies. The United Kingdom's establishment of a Royal Commission on Police Procedure and a Police Complaints Board in response to police brutality (Ross 2000b), the passing of the Parliament of Canada Act and the Canadian Security Intelligence Service Act (Corrado and Davis 2000), the Zorea, Blatman, and Karp Commissions in Israel (Miller 2000) and campaign finance reform laws in Japan (Potter 2000), are all examples of such internal controls. Suggested external controls within the state have included (1) media organizations, (2) interest groups, and (3) domestic non-governmental organizations (NGOs). External controls located outside of the state would include the United Nations (UN), the World Court (WC), the International Criminal Court (ICC) and, potentially, other states. As internationallysanctioned bodies, these organizations hold the power to apply sanctions to states which violate either international law or are overly abusive of their own citizens. However, the ability to back up sanctions with coercive force is limited to members who are willing to volunteer the necessary force to act in the organization's name. It is for this reason that U.S. violations of international law regarding nuclear weapons have gone unsanctioned (Kauzlarich and Kramer 1998). Also, economic organizations such as the World Bank (WB), the International Monetary Fund (IMF) and the World Trade Organization (WTO) represent potential controls on criminal states through the manipulation of financial assets, trade agreements, and trade sanctions. However, as other scholars have noted, these same institutions may directly or indirectly create the crimogenic conditions that 
lead to these types of atrocities (Friedrichs and Friedrichs 2007; Rothe, Muzzatti, and Mullins 2006; Rothe, Mullins, and Sandstrom 2008).

Controls have also been used to explain criminality. Tittle's (1995) Control Balance Theory was based on the premise that the amount of control to which an individual is subject compared to the amount of control the individual can exercise determines the probability of deviance. Tittle recognizes that constraints and controls constitute inhibitors of actions (if not actors). Control is not viewed in the context of a complete prevention but as a means that the actions can be limited; "control incorporates the idea of barriers, or constraints" (Tittle 1995, 143). Tittle refers to constraint as the probability (or perceived probability) that potential control will actually be exercised.

While Ross (2000) and Title (1995) provide valuable insight into controls and constraints, we believe these are not conceptually interchangeable. Phenomenologically, a constraint differs from a control in that it is an inhibitor or barrier that occurs at the onset of or during an illegal action. This constraint can act as a complete blockage to the act, or it can act as a restraint, that inhibits or causes the actor(s) to find alternative means to crime enactment. A control, on the other hand, is a formal mechanism meant to block in full an illegal action or ideally hold accountable through prosecution, sanctions, or some form of social justice post-criminality. Having briefly reviewed some of the key contributions to our proposed integrated theory, we now turn to what we believe is a comprehensive tool that can aid the systematic study and explanation of the worst crimes known to humanity.

\section{An Integrated Theory of International Criminal Violations}


With the complexities of these crimes, it is necessary to examine catalysts and inhibitors at all levels of analysis. In doing so, the integrated theory we propose combines insights from criminological theory that help to explain the multiple levels at play within each specific case. Any given incident of international crime is a product of a myriad of social forces which come together in the production of the event in question. Thus, attention must be given to specific time-space. Global political and economic conditions are one variable that makes these crimes more or less likely, provide tensions and contradictions for countries to navigate, and present problems for state actors to resolve-either criminally or legally. Contextualization of such acts is essential to understand both the idiosyncrasies of an individual event as well as the patterns which emerge in the phenomena as a whole.

Moreover, any given crime is a product of multiple catalysts and forces; to fully elucidate a singular occurrence, one must examine a number of factors at multiple levels of analysis. Consequently, our theoretical model recognizes the necessary catalysts of motivation, opportunity, constraints and controls for each of these levels. As such it contains both breadth and depth. Building upon the early works of Kramer and Michalowski (1990), Kauzlarich and Kramer (1998), Rothe and Mullins (2006), and Mullins and Rothe (2007), we present an integrated theory of international criminal law violations and state offending that recognizes the inherent complexity of these phenomena. Such analytical acuity allows a precise pin-pointing of key forces and how they interact within a specific criminal event or context (see Figure One).

[Figure One About Here]

\section{Motivation}


Unlike some criminological theories that assume motivation is either mundane or unimportant (e.g., most control, routine activities, and deterrence theories), especially for the crimes examined here, we feel motivation is a crucial theoretical component. The assumption of motivation being consistently present, and as such irrelevant to consider, can be linked back to the classical school perspective wherein human nature is perceived as hedonistic. While we agree with key postulates of Routine Activities Theory, the elements of a motivated offender, suitable targets (opportunity), and capable guardians (operationality of control), and the concept of bounded rationality that illuminates situational factors, we do not agree that "criminal inclination is a given and... [we need to] examine the manner in which the spatio-temporal organization of social activities helps translate their criminal inclinations into action" 1979:589). Rather, we see motivation as an essential variable to be explained. The complex psychological, social and cultural factors (as well as interactions among these factors) which produce motivation are not so easily dismissed. We do not believe that the drive to genocide or mass atrocity is inherent in all human cognitive processes that merely need to be controlled.

Those theories that assume motivation tend to resort to simplistic explanations that take for granted the rewards of crimes are self-contained and self-evident. However, especially for genocide, war crimes and crimes against humanity, the acts are not necessarily inherently rewarding, nor do they necessarily involve hedonistic tendencies or other seemingly innate human psycho-social drives. If they were, such wide spread criminal atrocities would be much more common than they are, especially considering the derth of controls on such behaviors. 
Motivation is the constellation of the general and specific drives that lure and entice a given organization and/or organizational actor toward offending. Specific motivating forces can include the enhancement and/or maintenance of political power (e.g., the LRA's focused attempts to overthrow the Museveni regime), personal or organizational economic gain (e.g., the Janjaweed and its members), access to valuable natural resources (e.g., multiple forces within the DRC fighting over control of the mines in the mineral rich northeast and southeast), religious factors (e.g. the LRA), or revenge (e.g., the Hutu). Often, these factors interact with others to create more intensely motivated populations. As an example, the primary motivation of LRA fighters is their belief that their struggle against the Museveni regime is a divine calling directed and guided by God through the prophet Joseph Kony. Additionally, the LRA leadership is driven by political and personal desires for power. Many soldiers within the LRA are remnants of older, defeated militaries which seek revenge against the Museveni regime. General motivations, while often linked to specific, can include factors such as political marginalization of a specific group or party (e.g., colonial powers often marginalized a portion of the population, giving specific preferential treatment to one group). In turn, this can result in specific motivating factors including political or economic gain. Further, ethnic divisions that were created by either colonial or post-colonial authorities can lead to specific motivation including revenge and/or the destruction of the reified 'dehumanized other'. Additionally, it must be acknowledged that while we identify general (or modal) motivation factors, there can also be a wide variety of motivations individually within a criminal group (see Smeulers 2007).

\section{Opportunities}


Opportunities are those social interactions where the possibility for a crime to be committed emerges and presents itself to a motivated offender (see Felson 1998). While all the motivation in the world may be present without opportunity there cannot be a commission of a crime. Further, just as Cloward and Ohlin (1963) stated, the presence of legitimate and illegitimate opportunity must be taken into account. This is especially true give the use of international law as a standard for defining the criminality.

As an example at the macro-level, being a state strongly enhances the ability to create and capitalize upon criminal opportunity. Even the poorest countries have tremendous amounts of human and financial capital to draw upon for crime commission. On the other hand, the desirability of drawing upon illegal means will be even more tempting when legal means of accomplishing the goals are absent, blocked, or constrained. Further the inaction of local or international bystanders will also facilitate the generation of opportunity (see Grunfeld 2007). On the meso-level, opportunity for specific actors is affected by the larger culture and/or state structure. For example, in the case of the Sudanese genocide, the opportunity for the Janjaweed to commit the crimes against humanity thus far has been provided by the el-Bashir regime's collusion. The opportunity for the LRA to commit atrocities and continue in a 20 year long conflict was largely been created by the direct economic and social support of the Sudanese government as well as their de facto control of the northern hinterlands.

\section{Constraints}

Constraints are those social elements that stand to potentially make a crime either riskier or less successful; offenders must navigate around a constraint. We envision these as taking several forms, including what other scholars have defined as controls: 
international reactions; political pressures; public opinion, international social movements, oversight from agencies such as the United Nations; political pressures; media scrutiny; and socialization. Simply, a constraint differs from a control in that constraints are not expected to fully control or block state or organizational crimogenic behaviors, nor do they act to penalize violators. Instead, by definition they serve as potential barriers before or during an act (Rothe and Mullins 2006). Nonetheless, states are often in unique positions to both navigate around extant constraints and/or to neutralize the power they represent. For example, Sudan was able to circumvent the constraints NGO's represented by curtailing the ability of aid workers to effectively monitor the regime's activities or have access to civilians that provide testimony of the abuses. Additionally, states can attempt to neutralize international pressures by rhetorically framing the events in question as "insurgent activity" and/or cases of general banditry by militias. When organizations are sponsored by the government, they are effectively freed from potential constraints of the population or foreign involvement. Having said this, a constraint's ineffectiveness does not negate its presence. Minimally, additional actions are required by the criminal actor which led to additional costs, be they real or opportunity. Further, the power of constraints to stymie criminal actions can be enhanced by examining how states negotiated prior constraints.

\section{Controls}

A control is a complete blockage to an act or when a criminal penalization is ideally inevitable after the fact. This means that conceived criminal action will not occur and, if it does, ideally there will be legal repercussions. Of course, there is no such thing as noting is universal or inevitable. Unlike constraints, we view controls as institutions 
that have the ability to stave off or prevent entirely the criminal action or to ideally address such violations as an after-the-fact mechanism in the form of accountability. With any type of offending this typically is in the form of formal social controls such as laws and/or regulations that can act as deterrents or provide accountability, punishment, or sanctions.

. As a control, laws are indeed present and as was noted by Rothe and Mullins (2006c; 2007), deterrence based on extant laws should be more promising for actors committing crimes that constitute violations of international criminal law than that of traditional street crime being deterred by laws due to the social integration and position of most potential offenders. As street crime and white collar crime research has shown, social location and position strongly influences deterrence (see for example, Berk at el 1992; Paternoster and Piquero 1995; Paternoster and Simpson, 1996; Piquero and Paternoster, 1998; Stafford and Warr, 1993). Those actors most likely to be involved in these types of crimes would seem to be those who are most influenceable by law. On the other hand, the work of Tittle (1995) suggests that the social positions and general practices of militia leaders would not be as likely to be deterred by the law due to the levels of power and control they wield. Consequentially, deterrence could potentially only serve as a control if continued prosecutions for these types of crimes occur via the International Criminal Court (ICC). For example, the ICC claims that their indictments have simultaneously reduced the violence within Northern Uganda and compelled the LRA back into peace talks (Agirre 2007). Further, such controls can also be nationally generated but locally implemented (e.g., the Gacaca's in Rwanda, see Havemen 2007, or any court in the world). 


\section{Causal Logic}

While our discussions above identifies and describes key etiological factors functioning at all levels of analysis, in and of itself, the discussion does not specifically identify and discuss causal relations. In order to build a thoroughly predictive model, something not yet done with the core of the integrated model we present above, we specify and detail such relationships. (see Figure two).

[figure two about here]

We have presented a complicated theory of complicated phenomena. To elucidate the causal relationship among the important catalysts we discuss above, we have found it necessary to draw upon the idea of nodes of interconnection (Tittle 1995). Following Control Balance theory, we propose that the various elements of theoretical significance examined above will come to influence social structure and behavior through nodes (e.g., those boxes numbered 1-4 in Figure Two). While the important theoretical issues operate at multiple levels of analysis, at the end of the day, so to speak, a crime is still committed by an individual social actor acting based upon decision making processes. Yes, crimes have macro-level causes and in many cases the social actor of interest is a component of a social organization instead of an atomistic individual, the specific criminal action is still individualized in its commission (even if the unit of analysis or explanation is organizations a singular or very small group of people still make the decision to offend). Thus, one should examine the aggregate effects of a catalyst at the different levels of analysis above the micro level as they come together to create a social force. While it is possible, for example, to identify motivational forces at all four levels of analysis, 
functionally, they all produce motivation within individuals (and organizations for that matter).

The Opportunity node then represents combined supra-individual level forces that govern the presentation of opportunities to engage in violations of international criminal law. We see this set of combined opportunities, filtered through individual perception, as being positively related to micro-level motivation, which can in and of itself vary independently from the nodal influence. Then, micro-level motivation has a direct effect on crime commission and on micro-level motivation to offend (acknowledging the real possibility that one may be much more inclined to offend when presented with a clear opportunity to do so).

The Motivation node is similarly conceived. The various levels of motivating forces combine to jointly influence micro-level motivation for offending in a positive direction. Micro level motivation would be positively related to crime commission.

As constraints (and controls) tend to exist externally of individuals (save internal moral precepts), we conceive of all four levels of analysis combining in effect to create a singular Constraint node. The aggregate effects of constraints then act as a negative moderating effect on the translation of opportunity and motivation effects on offending behavior. Restated, we see constraints as not influencing (mediating) motivation or opportunity directly but rather as reducing the strength of the relationship between motivation and/or opportunity and offending. We propose the same set of conditions and relationships for the Control node. While constraints and controls block offending behavior, or at least alter enactment patterns, they do not necessarily in and of themselves reduce opportunity or motivation factors. Simply because raping a woman of a defeated 
population is prohibited by Geneva and Rome does not make a solider less desirous of doing so, nor does it ultimately reduce the nature of interactional opportunity an LRA combatant experiences when coming across a lone woman gathering firewood in the forest of Northern Uganda. Yet, such legal mechanisms may inhibit his acting on that combination of motivation and opportunity.

It is our hope that such a causal model allows researchers to move beyond the typical case study method used by most scholars of state crime or others studying crimes of this magnitude. It provides a model wherein key variables listed in the theoretical frame can be tested and can aid in the creation of a database for a met-analysis of the core and persistent etiological factors of atrocities.

\section{Conclusion}

By bringing mass atrocities to criminological attention, we hope to not only push the boundaries of the discipline itself but shine light on the nature of these mass violations of human life and dignity. Such instances of wide-scale violence present problems of interpretation that defy the use of any single extant theory in the field; our integrated theory provides the tools necessary to unpack these complex events and produce both singular and comparative explanations. While these crimes may be more difficult to study than other crimes, there are still numerous ways to gather and analyze data on these atrocities. Complex statistical analyses are not yet possible, but the compilation of data from existing sources provides hope for such work in the future.

Criminology as a disciple has shied away from the study of atrocity. Its selfdefinition has long been focused on street crimes and policies designed to curtail them. We see this as highly problematic. If criminology as a discipline cannot explain the 
worst crimes that humans commit, then it is not living up to its stated agenda. By bringing a criminological focus to these crimes we cannot only better understand the etiology of these events, we can better assess potential control modalities to reduce or eliminate future atrocities. In many ways, that is a much more essential task than mere academic explanation. Anything that can potentially reduce the amount of harm done by these crimes is well worth the effort and will go a long way to bringing more justice into the world. 
Figure One: Integrated Theory of International Criminal Law Violations

\begin{tabular}{|c|c|c|c|c|}
\hline \multirow{6}{*}{$\begin{array}{l}\text { International } \\
\text { Level }\end{array}$} & Motivation & Opportunity & Constraints & Controls \\
\hline & Political Interests & $\begin{array}{l}\text { International } \\
\text { Relations }\end{array}$ & $\begin{array}{l}\text { International } \\
\text { Reaction }\end{array}$ & International Law \\
\hline & Economic Interests & $\begin{array}{l}\text { Economic } \\
\text { Supremacy }\end{array}$ & Political Pressure & $\begin{array}{l}\text { International } \\
\text { Sanctions }\end{array}$ \\
\hline & Resources & $\begin{array}{l}\text { Military } \\
\text { Supremacy }\end{array}$ & Public Opinion & $\begin{array}{l}\text { Economic } \\
\text { Institutions }\end{array}$ \\
\hline & Ideological Interests & $\begin{array}{l}\text { Complementary } \\
\text { Legal Systems }\end{array}$ & $\begin{array}{l}\text { NGOs/Social } \\
\text { Movements }\end{array}$ & \\
\hline & & & Oversight & \\
\hline \multirow[t]{5}{*}{ Macro Level } & $\begin{array}{l}\text { Structural } \\
\text { Transformations }\end{array}$ & $\begin{array}{l}\text { Availability of } \\
\text { Illegal Means }\end{array}$ & Political pressure & Legal Sanctions \\
\hline & Economic Pressure & $\begin{array}{l}\text { Control of } \\
\text { Information }\end{array}$ & Media scrutiny & Domestic Law \\
\hline & Political Goals & Propaganda & Public Opinion & \\
\hline & Ethnogenses & & Social Movements & \\
\hline & Anomie & & Rebellion & \\
\hline \multirow[t]{3}{*}{ Meso Level } & $\begin{array}{l}\text { Organizational } \\
\text { Culture and goals }\end{array}$ & $\begin{array}{l}\text { Communication } \\
\text { structures }\end{array}$ & Internal Oversight & Codes of Conduct \\
\hline & $\begin{array}{l}\text { Authoritarian } \\
\text { Pressures }\end{array}$ & Means availability & $\begin{array}{l}\text { Communication } \\
\text { Structures }\end{array}$ & \\
\hline & Reward Structures & Role specialization & $\begin{array}{l}\text { Traditional } \\
\text { authority structures }\end{array}$ & \\
\hline & & & & \\
\hline \multirow[t]{4}{*}{ Micro Level } & Socialization & Group think & Socialization & Legitimacy of Law \\
\hline & $\begin{array}{l}\text { Individual Goals } \\
\text { and ideologies }\end{array}$ & $\begin{array}{l}\text { Diffusion of } \\
\text { Responsibility }\end{array}$ & $\begin{array}{l}\text { Obedience to } \\
\text { Authority }\end{array}$ & $\begin{array}{l}\text { Perception of } \\
\text { reality of law } \\
\text { application }\end{array}$ \\
\hline & $\begin{array}{l}\text { Normalization of } \\
\text { Deviance }\end{array}$ & $\begin{array}{l}\text { Perceived Illegal } \\
\text { Means }\end{array}$ & & Personal Morality \\
\hline & $\begin{array}{l}\text { Definition of the } \\
\text { Situation }\end{array}$ & & & \\
\hline
\end{tabular}


Figure Two: Causal Model

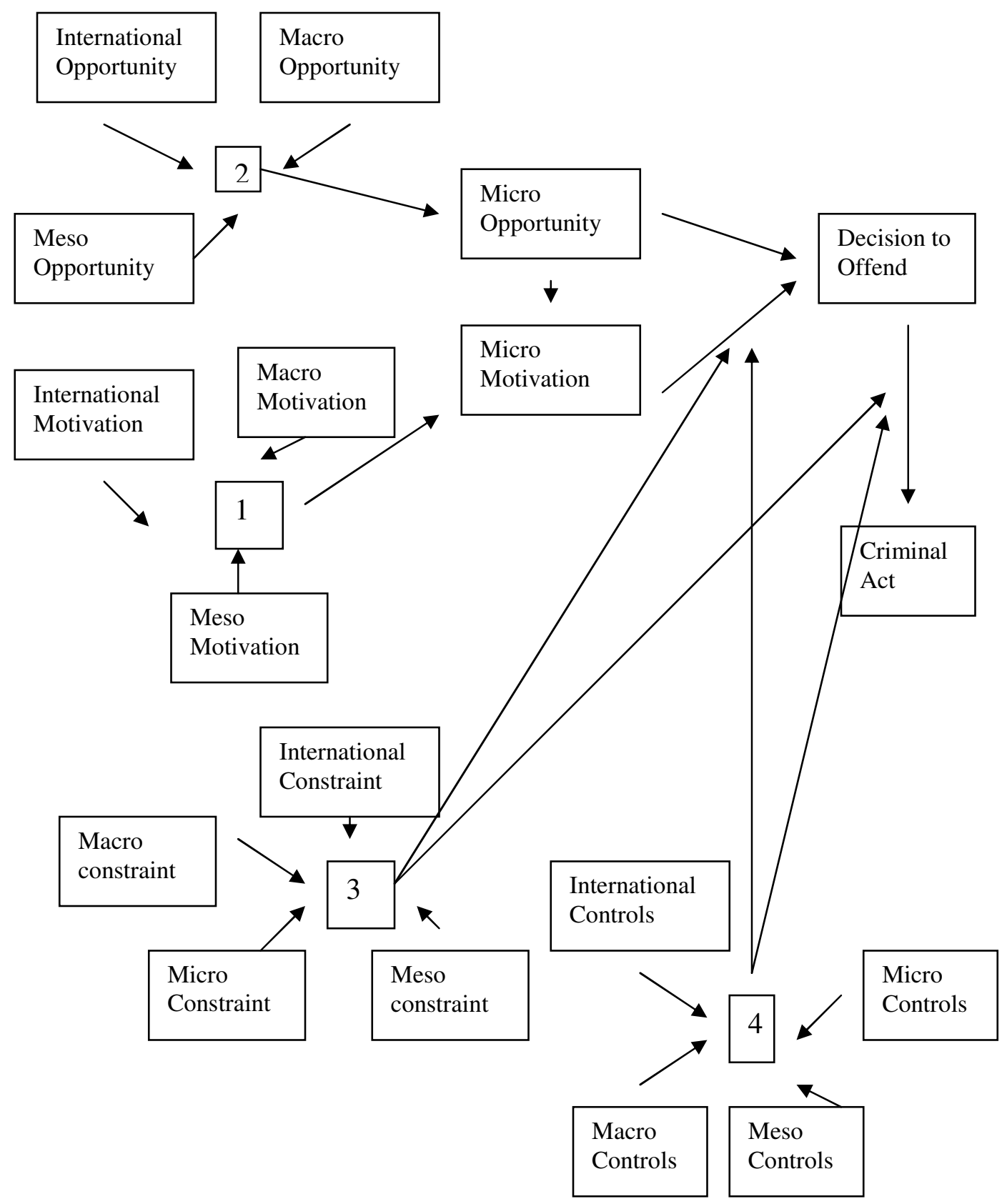

Node $1=$ Opportunity

Node $2=$ Motivation

Node $3=$ Constraints

Node $4=$ Controls 


\section{Reference:}

Agirre, Xavier. 2007. Personal Communication 14 April 2007.

Amadiume, Ifi and An-Na'im, Abdullahi (eds) (2000) The Politics of Memory: Truth, Healing and Social Justice. London: Zed Books.

Bassiouni, M. Cherif (2006) Crimes of War: The Book. Retrieved from

http://www.crimesofwar.org/thebook/crimes-against-humanity.html.

Berk, Richard, Alec Campbell, Ruth Klap, and Bruce Western (1992) 'The deterrent effect of arrest in incidents of domestic violence: A Bayesian analysis of four field experiments', American Sociological Review. 57: 698-708.

Bijleveld, Catrien (2007) 'So many missing pieces: Some thoughts on the methodology of the empirical study of gross human rights violations', Paper presented at the Expert Meetings at Maastricht University. 13-14 April.

Bursik, R. J. Jr. and H. G. Grasmick (1993) Neighborhoods and Crime: Effective Dimensions of Effective Community Control. New York: Lexington Publishers.

Cassesse, Antonio (2002) The Rome Statute of the International Criminal Court: A Commentary. Vol. I. New York: Oxford Press.

Cobban, Helena (2007) Amnesty After Atrocity: Healing Nations After Genocide and War Crimes. Boulder, London: Paradigm Publishers.

Felson, Marcus (1998) Crime and Everyday Life. $2^{\text {nd }}$ edition. Thousand Oaks, Ca: Pine Forge Press.

Friedrichs, David and Jessica Friedrichs (2002) 'The World Bank and Crimes of Globalization: A Case Study', Social Justice 29: 13-36.

Grunfeld, Fred (2007) 'The role of bystanders in Rwanda and Srebrencia', Paper presented at the Expert Meetings at Maastricht University. 13-14 April.

Hagan, John and Alberto Palloni (2006). 'Death in Darfur'. Science 15 313(5793): $1578-1579$.

International Court of Justice (ICJ) (2005) 'The Court'. Online. <www.icjcij.org/court/index.php?p1=1\&PHPSESSID=7b883991ec91e9ad2e7e822d149a87 ff $>$

Kauzlarich, David and Ronald Kramer (1998) Crimes of the American Nuclear State: At Home and Abroad. Boston: Northeastern University Press. 
Kramer, Ronald and Raymond Michalowski (2005) 'War, Aggression, and State Crime: A Criminological Analysis of the Invasion and Occupation of Iraq', British Journal of Criminology 45 (4): 446-469.

(1990) 'Toward an Integrated Theory of State-corporate Crime', Presented at the American Society of Criminology. Baltimore, MD.

Lemkin, Raphael (1944) Axis Rule in Occupied Europe. Washington, DC: Carnegie Endowment for International Peace.

Mullins, Christopher W. and Dawn L. Rothe (2007) 'Darfur: The Forgotten Ones', Critical Criminology. 15(2)

Orentlicher, Diane (2006) Crimes of War: The Book. Retrieved from <www. crimesofwar.org/thebook/genocide.html.

Parlevliet, Michelle (1998) 'Considering truth. Dealing with a legacy of gross human rights violations', Netherlands Quarterly of Human Rights 16: 141-174.

Parmentier, Stephan, Kris Vanspauwen, and Elmar Weitekamp (2001) 'Restorative justice for victims of mass violence:Reconsidering the building blocks of post-conflict justice', Paper presented at the Expert Meetings at Maastricht University. 13-14 April.

Paternoster, Rayond and Alex Piquero (1995) 'Reconceptualizing deterrence: An empirical test of personal and vicarious experiences', Journal of Research in Crime and Delinquency. 32(3): 251-287.

Paternoster, Raymond and Sally Simpson (1996) 'Sanction threats and appeal to morality: Testing a rational choice model of corporate crime', Law and Society Review 30: 549-583.

Piquero, Alex and Raymond Paternoster (1998) 'An Application of Stafford and Warr's reconceptualization of deterrence to drinking and driving', Journal of Research in Crime and Delinquency. 35(1): 3-39.

Prunier, Gerard. (2005) Darfur: The Ambiguous Genocide. Ithica, NY: Cornell University Press.

Rothe, Dawn and Christopher W. Mullins (200) 'Darfur and the International Legal Order: Genocide or Crime against Humanity?' Humanity and Society. 31(1):83-107.

Rothe, Dawn and Christopher W. Mullins (2006a), 'International Community: Legitimizing a Moral Collective Consciousness.' Humanity and Society. 30(3):254-276.

Rothe, Dawn and Christopher W. Mullins (2006b) 'The International Criminal Court and United States Opposition', Crime, Law and Social Change. 45:201-226. 
Rothe, Dawn and Christopher W. Mullins (2006c) The International Criminal Court: Symbolic Gestures and the Generation of Global Social Control. Lanham, MD: Lexington Books.

Rothe, Dawn, Christopher W. Mullins, and Kent Sandstrom (2008), 'The Rwandan Genocide: International Financial Policies and Human Rights' Social Justice (forthcoming)

Rothe, Dawn; Stephen Muzzatti; and Christopher W. Mullins (2006) 'Crime on the high seas: Crimes of globalization and the sinking of the Senegalese ferry Le Joola', Critical Criminology. 14:2: 159-180.

Sadat, Leila Nadya and S. Richard Carden (2000) 'The new international criminal court: An uneasy revolution', Georgetown Law Review. 88: 381-474.

Sands, Phillip (2005) Lawless World: America and the Making and Breaking of Global Rules. London: Allen Lane.

Shaw, C R. and H D. McKay (1942) Juvenile Delinquency and Urban Areas. Chicago Il: University if Chicago Press.

Smeulers, Alette (2007) 'Towards a typology of perpetrators of international crimes and other gross human rights violations', Paper presented at the Expert Meetings at Maastricht University. 13-14 April.

Stafford, Mark and Mark Warr (1993) 'A reconceptualization of general and specific deterrence'. Journal of Research in Crime and Delinquency 30(2): 123-35.

Tittle, Charles (1995) Control Balance: Toward a General Theory of Deviance. Boulder, CO: Westview Press.

Truth and Reconciliation Commission of South Africa (1998) Truth and Reconciliation Commission of South Africa Report. Volume One (Cape Town: Juta Publishers).

Whyte, D. (2003) 'Lethal Regulation: State-Corporate Crime and the United Kingdom Government's New Mercenaries', Journal of Law and Society, 30/4: 575-600.

\section{Treaties, Laws, Etc. Cited}

Agreement for the Prosecution and Punishment of the Major War Criminals of the European Axis and Charter of the International Military Tribunal, 1945.

The Convention on the Prevention and Punishment of the Crime of Genocide, 1948.

The Hague Convention, 1907. 
Charter of the International Criminal Tribunal for Rwanda, 1994.

Charter of the International Criminal Tribunal for Yugoslavia, 1993.

International Court of Justice Ruling: Yugoslavia v. Bosnia 2001.

International Court of Justice Ruling: Bosnia and Herzegovina v. Yugoslavia. 2001.

Rome Statute of the International Criminal Court, 1998.

Treaty of Versailles, 1919.

The United Nations Convention for the Amelioration of the Condition of the Wounded and Sick in Armed Forces in the Field, 1948.

\section{Notes}

\footnotetext{
${ }^{\mathrm{i}}$ The term genocide was originally coined by Ralph Lemkin in 1933 . Lemkin suggested a treaty should be created to make attacks on religious, ethnic, or national groups an international crime. He called this genocide: from the Greek word genos, meaning race or tribe, and cide, the Latin term for killing. Four years passed before genocide was recognized as an international crime by treaty. However, the legal foundation was first put in place during the 1945 Nuremberg Trials and subsequent Nuremberg Charter. Genocide was used in the indictment against the Nazi war criminals that stated that those accused "conducted deliberate and systematic genocide...the extermination of racial and national groups, against the civilian populations of certain occupied territories in order to destroy particular races and classes of people and national, racial or religious groups" (Orentlicher 2006:2). Nuremberg prosecutors also invoked the term in their closing arguments. While the Nuremberg Charter did not use the term genocide per se, its definition of crimes against humanity was very close to the idea of genocide Lemkin proposed. The difference was the requirement of specific intent in the case of genocide, which is lacking in the definition of crimes against humanity. In 1946, the United Nations General Assembly adopted a resolution establishing genocide as an international crime, defining genocide as "a denial of the right of existence of entire human groups, as homicide is the denial of the right to live of individual human beings" (Resolution 95 (1)). In 1948, The Convention on the Prevention and Punishment of the Crime of Genocide was adopted by the United Nations. Article 1 states that "the Contracting Parties confirm that genocide, whether committed in time of peace or in time of war, is a crime under international law which they undertake to prevent and to punish" (General Assembly resolution 260 A (III)). Thus genocide may be committed by an individual, group, or government, against one's own people or another, in peacetime or in wartime. This last point distinguishes genocide from "crimes against humanity," whose legal definition specifies wartime. Additionally, the Convention obligates state party members to "prevent and punish" genocide. Since its development in 1948 there has been a dearth of precedents that enforced the Convention. Specifically, it was not until the 1990's that the international arena prosecuted acts defined as genocide: the establishment of the 1993 International Criminal Tribunal for Yugoslavia and 1994 International Criminal Tribunal for Rwanda. In 1998, with the development of the Rome Statute, the crime of genocide was again reaffirmed as an international crime with the requirements of both a physical element (comprising certain enumerated acts) and a mental element (intent). Specifically, Article 5 of the ICC lists genocide (and crimes against humanity) as a crime of "most serious crimes of concern to the international community as a whole." Genocide is then defined in Article 6. Both the physical and mental requirements of the 1948 Convention were carried over and included in the Rome Statute.

ii The international arena's early attempts to develop humanitarian law during the 19th and early 20th Centuries wholly focused on war crimes. The term crimes against humanity, however, originated in the
} 
1907 Hague Convention preamble that codified extant customary law of armed conflict ${ }^{\text {ii }}$. This was based on existing state practices derived from the values and principles deemed to constitute the laws of humanity (Bassiouni 2006). After World War I, in connection with the 1919 Treaty of Versailles, and relying upon the 1907 Hague Convention, a commission to investigate war crimes was created. In addition to war crimes committed by the Germans, the commission also found that Turkish officials committed crimes against the laws of humanity for killing Armenian nationals and residents during the period of the war (Bassiouni 2006:2). Such investigations set the framework for legitimating the idea of an international criminal law; a process that was to become codified after the next global conflict. In 1945 the United States and Allies developed the Agreement for the Prosecution and Punishment of the Major War Criminals of the European Axis and Charter of the International Military Tribunal (IMT), which defines and delineates crimes against humanity in Article 6(c). The Nuremberg Charter was the first document to establish crimes against humanity as a part of positive international law. The concept originated in order to prosecute Nazis and Japanese warlords for the atrocities of WWII that were outside of the existing 1907 Hague Conventions. Acts like the Nazi Holocaust cried out for international legal action, but there was no international law to draw upon. As many of these actions were not committed by uniformed armed forces on the field of battle, existing war crimes laws did not hold jurisdiction. Initially crimes against humanity was an ad hoc concept developed in response to idiosyncratic sets of events; since, the category has, become one of the central bodies of International Criminal Law. Crimes against humanity have been included in the statutes of the International Criminal Tribunal for the former Yugoslavia (ICTY) and the International Criminal Tribunal for Rwanda (ICTR), and the Rome Statute of the International Criminal Court (ICC). Specifically, Article 7 of which states that crime against humanity means any of the following acts when committed as part of a widespread or systematic attack directed against any civilian population, with knowledge of the attack: (a) Murder; (b) Extermination; (c) Enslavement; (d) Deportation or forcible transfer of population; (e) Imprisonment or other severe deprivation of physical liberty in violation of fundamental rules of international law; (f) Torture; (g) Rape, sexual slavery, enforced prostitution, forced pregnancy, enforced sterilization, or any other form of sexual violence of comparable gravity; (h) Persecution against any identifiable group or collectivity on political, racial, national, ethnic, cultural, religious, gender; (i) Enforced disappearance of persons; (j) The crime of apartheid; (k) Other inhumane acts of a similar character intentionally causing great suffering, or serious injury to body or to mental or physical health. Indeed crimes against humanity have come to "mean anything atrocious committed on a large scale" (Bassiouni 2006:1). Further, this body of law governs the behaviors not only of states and state actors, but also of quasi-military bodies (e.g., militias), transnational organizations and of individuals.

iii European-based cultures have been formally developing and refining the notion of war crimes--illegal actions which occur on the field of battle--since the 1800s. As technologies of warfare became increasingly lethal, and civilians increasingly victimized, western nations moved to limit the types of weapons and tactics used. The late 1800s and early 1900s saw numerous multi-lateral treaties entered into, only to be violated in subsequent conflicts. The end of World War I saw these laws first coupled with enforcement mechanisms, though the tribunals were piecemeal and largely symbolic. After World War II, The Nuremberg and Tokyo tribunals set the international standard for the convening of special courts to try cases of war crimes and crimes against humanity. These tribunals were initiated by, and governed under, the Nuremberg principles, whose primary purpose was to establish a set of guidelines for defining and identifying war crimes. Principle VI (b) defines War crimes as: Violations of the laws or customs of war which include but are not limited to, murder, ill-treatment or deportation of slave labor or for any other purpose the civilian population of or in occupied territory; murder or ill-treatment of prisoners of war or person on the Seas, killing of hostages, plunder of private or public property, wanton destruction of cities, towns or villages or devastation not justified by military necessity. While these principles were designed post hoc to try German Nazi and Japanese Imperial leaders they form the bedrock of later United Nations and the International Criminal Court's definitions. Following the Nuremberg principles, a complex set of definitions and rules of warfare were codified. Today, the term "war crime" typically refers directly to a violation of the four The United Nations Convention for the Amelioration of the Condition of the Wounded and Sick in Armed Forces in the Field and its attendant protocols. These laws are applicable to every state, as recognition by the United Nations requires ratification of the UN Charter and the ratification by the applicant state of these conventions. Geneva governs the ways in which armed forces are allowed to 
operate within theatres of battle and occupied territories. Specific laws govern weapons and tactics, allowable targets, treatment of medical and religious personnel, the treatment of prisoners, and how an armed force is to interact with non-combatants. For our purposes, the general rules of allowable targets are highly relevant, as most parties involved in the incidents target civilians and civilian areas. The rules of war also constrain the ways in which occupying forces are to administer, conquer and/or otherwise occupy territories. For example, an occupying force is not allowed to press the civilians into labor, plunder or loot the conquered territory. Any army must administer such resources in the best interests of the civilian population. While Geneva rests at the core of laws governing armed conflict, the 20th century has seen wide expansions of this legal code, with new crimes being defined to cover gaps or vagaries within the Geneva Conventions.

iv . These include operative goals, subunit goals, and managerial goals. 